\title{
Globalization versus Integration - The Quest for Appropriate Market System in the Philippines ${ }^{1}$
}

\author{
Arthur M. Alvendia (Corresponding author) \\ Alternative Development Initiatives Inc. \\ 7 Cecileville Street, White Plains, Quezon City, Philippines \\ E-mail: artalvendia@yahoo.com
}

Irina Kireeva

NCTM O'Connor, Avenue de la Joyeuse Entrée, 1, Brussels, Belgium

E-mail: i.kireeva@nctm.it

Received: October 23, 2013 Accepted: December 18, 2013 Published: January 11, 2014

doi:10.5296/ijssr.v2i1.4449

URL: http://dx.doi.org/10.5296/ijssr.v2i1.4449

\begin{abstract}
The Philippines is essentially a nation of micro and small producers living in a group of islands that is very rich in agricultural, fisheries, forest, mineral, and touristic resources. Hence, the participation of this nation in the global economy should be grounded on this structure and resource endowment. While these define the demographic and economic makeup of the Filipino, it is his deep socio-political and moral belief in freedom and capitalism that has shaped his psycho-cultural make-up. It is his deep conviction that progress must come with and

\footnotetext{
${ }^{1}$ A word of appreciation and thanks for suggestions on the earlier text and title, as well as encouragement during the work on this article is due to Mr. Bernard O'Connor, senior partner of the firm NCTM O'Connor, Mr. Alloys Mutabingwa, a lawyer from Rwanda, former Deputy Secretary-General of the East African Community Secretariat, Mr. Richard Moody, EU Special Agricultiral Policy Adviser to the Government of Moldova and the Associate Professor at the Law School of Shandong University, Jinan City, P. R. China (at the time of writing this article, a Guest Researcher at the Max Planck Institute for Intellectual Property and Competition Law), Dr. Xiaobing Wang. The opinions expressed in the article or any mistakes are those of the authors.
} 
thru the exercise of civil liberties, that has led to a doctrinaire adherence to market economics enforced by a rigid institutional systems in finance, governance and laws.

\section{Running title: Finding the Filipino Identity - Building in the Way of Freedom}

Keywords: micro and small enterprises, agriculture, global economy

\section{Introduction to the Issue of Integration - "The Test of Civilizations"}

Like waves in the ocean, civilizations ${ }^{2}$ and their social systems pass; rising, peaking and descending in power and dominion then rising again to start a new integration. Ironically, the turning point of the tide is at the peak, when the system rules triumphant, it seeks to be universal, attaining some kind of cultural hubris, then the system's limits and contradictions appear, to signal its descent.

One may say that the last decade of the millennium, saw the triumph of democracy and capitalism to become the dominant political and economic order for "building the world". The tandem ideology was said to be "the end of history" (Fukuyama, 1992: The End of History and the Last Man $)^{3}$ as the end state of the evolution for the quest for social order - a kind of modern day "Camelot" " which would govern a "good society". This achievement was itself the result of a three hundred year journey of human civilization, founded on the radical ideas of the Enlightenment i.e., - of "political freedom, equality, the right to individual pursuit of happiness, the concept of private property, the use of reason and economic efficiency in governance, the liberal role of government and the freedom of private enterprise". These

\footnotetext{
${ }^{2}$ The word "civilization" is a controversial term used in several related ways. Primarily, the term has been used to refer to human cultures, which are complex in terms of technology, science, politics and division of labour. In modern academic discussions however, there is a tendency to use the term in a more neutral way to mean approximately the same thing as "culture" and can refer to any human society (for example, "Ancient Greek Civilization") associated with any particular geographical location at a particular time, historical or current.

${ }^{3}$ This book by Yoshihiro Francis Fukuyama (an American philosopher, political economist, and author, born on 27 October 1952) is expanding on his 1989 essay "The End of History?", published in the international affairs journal "The National Interest". In this book, Fukuyama argues that the advent of Western liberal democracy may signal the end point of humanity's sociocultural evolution and the final form of human government. Noteworthy in particular the following statement: "What we may be witnessing is not just the end of the Cold War, or the passing of a particular period of post-war history, but the end of history as such: that is, the end point of mankind's ideological evolution and the universalization of Western liberal democracy as the final form of human government".

${ }^{4}$ Camelot is the most famous castle and court associated with the legendary King Arthur. Camelot first appeared in 12th-century French romances and eventually came to be described as the fantastic capital of Arthur's realm and a symbol of the Arthurian world. The stories locate it somewhere in Britain and sometimes associate it with real cities, though more usually its precise location is not revealed. Most scholars regard it as being entirely fictional, its geography being perfect for romance writers. Arthurian scholar Norris J. Lacy commented that "Camelot, located no where in particular, can be anywhere". Nevertheless arguments about the location of the "real Camelot" have occurred since the 15th century and continue to rage today in popular works and for tourism purposes.

5 The Age of Enlightenment (or simply the Enlightenment) is the era in Western philosophy, intellectual, scientific and cultural life, centered upon the 18th century, in which reason was advocated
} 
building principles and social concepts have provided the structure and components to build the institutional systems of a materially progressive and liberal global society.

At the same time, a question can be raised whether the economic power blocks and institutional (including legal and administrative) barriers evolved by the market itself, have effectively disenfranchised the masses of micro-small producers and trapped them structurally in a vicious cycle of smallness and low productivity. The marginalized masses within the countries exist in every economy; however, the reality shows that in less developed countries those masses being a majority of the population are often not represented at all by the policy positions of their governments and their political-economic institutions. The interests of the greater majority of the lower income class are often in conflict with the positions taken by their governments. This is a fact that cannot be denied easily.

This situation has raised a fundamental question, which each country or nation is compelled to answer, as the tsunami waves of the "globalization order" has spread throughout the earth: Can Capitalism, the economic system that established and governs globalization, be the same system to achieve integration of the marginalized masses in one's country? Is integration possible within the order of globalization, or does Globalization, in fact, contradicting Integration? This is a crucial question that confronts every nation in this era of globalization of a social order premised on the triumph of capitalism and democracy. How nations, institutions and leaders respond, will determine the path of development and the integration of its marginalized sectors.

The article examines the two sources of "answers" to this question.

- One is the "globalization paradigm" or "vision of order". It is essentially a belief premised on a system that is based on the theory of rational economic choice, which has evolved into a socio-political and moral philosophy that provides additional rationale and established an Institutional System ${ }^{6}$ for economic governance. This has now been advocated by economists of the developed countries. Their belief is that globalization economics will eventually resolve the economic problems of the marginalized sectors as progress enables more of them to integrate with the mainstream economy.

- Two is the "reality record" of recent economic history of some individual nations (both developed and developing), which provides at least fifty years of factual information on how the economic system under capitalism has performed, and how it has evolved into

as the primary source for legitimacy and authority. It is also known as the Age of Reason. In his famous essay "What is Enlightenment?" (1784), Immanuel Kant described it simply as freedom to use one's own intelligence.

6 "Institutional System", where the term "institution" as used in this article refers to "patterns of thinking and human behavior". This includes all forms of human behavior, including beliefs, values, principles, policies, laws, organizations, language, religion, culture and tradition. "Institutional System" refers to the hierarchic structure of institutions, which reflect the chain of cause and effect of - a building decision or choice. 
a socio-political-moral philosophy, embedded in an institutional system interacting with other systems in a multi-dimensional social space.

The purpose of this article is to address the challenge of integration to a globalizing civilization. The article highlights the critical role of the institutional system evolved by globalization. The institutional system refers to the building systems of society, i.e., its implementing mechanisms, structures, relationships, functional elements or means - to translate its fundamental values to reality and achieve its goals or vision. The institutional systems refer to the set of collective functional systems (socio cultural, moral, philosophical, political, economic, technological, legal, administrative), which provide the answers to the fundamental components of the task of building, i.e., the why, who, what, where, how of building and thereby largely pre-determine the building choice and its outcome.

The institutional system of globalization defines a building system premised primarily on ideal economic conditions of free trade, free enterprise, perfect competition, no dominant economic player, or intervening political forces. These conditions do not obtain in a feudal third world country like the Philippines. Similar to the granting of fiefs (feudal lands) to vassals by the English lords, Spain the longest colonizer of the Philippines gave large tracts of lands to favored families, which became haciendas. This became the historical root of a feudal oligarchic society and economy that emanated from the concentration of wealth and power among the few landed and educated elite.

The oligarchy and educated elite have fostered a doctrinaire interpretation of free market theory and application of its economic logic, despite the deviation of social realities in the feudal economy from the theoretical conditions necessary to enable market competition achieve economic efficiency. The ruling elite have sustained and protected an institutional system premised on this economic logic, as the universal path to economic progress and presumably to eventual integration of the marginalized masses. The article evaluates whether this economic logic of globalization can indeed resolve the issue of integration.

To resolve the integration issue, the first task is to recognize and understand the nature and structure of this systemic contradiction between globalization and integration. The article does this by tracing the historical outcome of applying the logic of economic efficiency in a third world feudal country, which has been a strong adherent of free market capitalism. The article analyzes these historical results of capitalism's capacity to integrate, and the implications on both the intellectual and institutional foundations of this economic system. Specifically, the case of the Philippines is taken as a useful test case precisely because of its strong doctrinaire adherence to the globalization policy regime of economic efficiency and, yet, has one of the worst-case examples of mass marginalization.

This article shows that it is precisely the logic, misperceptions, and workings of market competition (in a third world feudal, oligarchic nation) that created institutional structural distortions, which eventually has led to the long stagnation of the overall Philippine economy and systemic barriers that have entrapped the masses of micro-small enterprise into different types of institutional barriers or structures evolved by the market. 
These areas of misapplication have become the reason and the point of system impasse or gridlock and therefore the principal obstacles of development. The authors consider that a doctrinaire interpretation of economic efficiency (as declared by neoclassical economics propagated by globalization proponents), is the principal institutional and intellectual barrier to make the "informed choices" needed to bring systemic change and achieve integration of the marginalized sectors. In this theoretical interpretation, economic freedom is deemed to pursue rational choice, and rationality is defined solely by what is economically efficient or maximizes profit within the context of the given technical and institutional situation, irrespective of the normative acceptability of the prevailing social conditions and institutional system. The thesis is efficiency will bring economic progress and resolve these social conditions or institutional issues that may have brought about marginalization.

\section{Systemic Impact of Capitalism: The Philippine Case - American Protégé for Democracy and Capitalism}

The Philippine experience with the reign of capitalism is an ideal test case for evaluating the impact of the free market system on a third world oligarchic country, precisely because of its faithful adherence to its tenets Free market capitalism came to the Philippines via the political vehicle of a Filipino revolution that had won independence from Spain (1898), only to be "stolen" by the Americans, who took over the Spanish surrender of its sovereignty over the colony after a simulated naval battle. ${ }^{7}$ The takeover was justified on the basis of the Monroe Doctrine of their "Manifest Destiny" to spread the message of freedom and equality through the social mechanism of free market -democracies. ${ }^{8}$ For almost fifty years the Filipinos learned and totally assimilated America's political economic ideology, including their legal system and culture. By the time the Americans left in 1946, the political, economic, institutional and legal systems, including culture and intelligentsia had become virtually a clone of America, and a people made "in our image" (Stanley Karnow, 1989: In Our Image: America's Empire in the Philippines).

Market economics with its systemic bias for the "powerful and rich" (because of economies of scale and control of scarce resources) sat well with the ruling landed class (so-called "hacienderos"), ${ }^{9}$ political families and bureaucrats who presided over the economy along

\footnotetext{
${ }^{7}$ The American military operations of May through August 1898 to conquer the Philippines from Spain during the Spanish American War, in particular, the Battle of Manila Bay, which took place on 1 May 1898. The American Asiatic Squadron under Commodore George Dewey engaged and destroyed the Spanish Pacific Squadron under Admiral Patricio Montojo y Pasarón. The engagement took place in Manila Bay in the Philippines, and was the first major engagement of the Spanish-American War.

${ }^{8}$ The Monroe Doctrine and Manifest Destiny were closely related ideas: historian Walter McDougall calls Manifest Destiny a corollary of the Monroe Doctrine (1823 - 1848). Manifest Destiny was the 19th century American belief that the United States was destined to expand across the North American continent, from the Atlantic Seaboard to the Pacific Ocean. It was used by Democrats in the 1840s to justify the war with Mexico; the concept was denounced by Whigs, and fell into disuse after the mid-19th century.

${ }^{9}$ From Spanish "hacienda" meaning estate. Some haciendas were plantations, mines, or even business factories.
} 
with the market winners and capitalists. The economy grew fast under American colonial rule, although the economic benefits remained limited to the top and marginalized the larger mass of the constituency of the young republic. But this inequality was nothing new to a feudal country, long dominated by the landed families and powerful politicos. The legal system along with the government's executive and legislative powers expanded and legitimized the outcome of the market no matter how unequal, flawed or oppressive the end results may be, because these have been the result of "free choice working through the market competition process".

In the social consciousness, the market system has been associated with the principles of free enterprise, consumer choice, the primacy of private enterprise, which emanate from basic human rights and values in a democracy. As such the resulting inequality was deemed inevitable and part of the "process of development". Subtly the institutional basis for the market system has now become a matter of human right, a deeply ingrained socio-political value, that is deemed more important than economic reason or the reality of a non-performing social system. From the rule of reason, the system rationale had migrated to become an ideology, and has become an economic religion.

There were great expectations after the declaration of independence in 1946, as the economy was rebuilt after the war. Growth set in as import substitution consumer industries were established, and agricultural, forestry and mineral resource exports grew.

In the 50's Philippines ranked second only to Japan in terms of economic development, ahead of its Asian neighbors. The World Bank declared the country "most likely to succeed", as the American protégé for democracy and market economics surged ahead. Import substitution started but mainly in the finished goods, while production goods remained dependent on imports of production inputs following market signals. Import substitution efforts were seen to be contrary to comparative market advantage, and did not receive long-term financial credit support, which was necessary to modernize industry. Continued dependence on imported production inputs placed a heavy toll on balance of payments, while its exports remained limited as industry failed to modernize to improve its competitiveness. By the early 70's, to save the country from its balance of payments recurring crisis, the country entered into the IMF stabilization program, and for the next thirty years became subject to its package of market economics policy prescriptions, as part of the "conditionality" for its financial support.

From the mid 70's the Philippines has had a long economic decline, which still has not bottomed. In the meantime, the country has been overtaken by its Asian neighbors (Singapore, Thailand, Korea, Malaysia, Taiwan), in what has been called the "East Asian Miracle". The miracle growth has been attributed to these countries' pragmatic political approach, often running counter the standard policies of the Washington prescription of market economics, as they supported their industrialization with government investments, concessional long term loans to industry, protected markets, favored national investors, etc.

James Fallows described the phenomenon as the emergence of an Asian Model, in contrast to the Anglo-American capitalism (J. Fallows, 1994: Looking at the Sun. The Rise of the New East Asian Economic and Political System). The Asian Model of economic governance is a 
politically driven economics, empowering directly their constituents to become productive, making use of the market system as they see fit to their political objectives (rather than conforming to the conventional market policy and economic logic).

The Philippines did not follow the Asian Model and stuck to the Washington economic prescriptions associated with the American ideological belief that economic progress must come with political liberties, which should not be compromised by political intervention. This free market policy and ideological view held back government and private sector to jointly cooperate and undertake a more decisive strategy for state led investments or public private partnerships which East Asian neighbors did and proved to be effective. In the meantime the Philippine oligarchy used the market inspired institutional system to protect and expand their local market dominance.

In contrast, the Philippines have continued to decline economically, while the East Asian countries have continued to grow ahead of the Philippines, the market economics disciple. This has raised the question, what is really wrong? Is it because there is something inherently wrong in market economics, is it the leadership, or is it the institutional system associated with good economic governance?

The Philippines feudal beginnings and continuing oligarchy is reflected in the country's production profile, with $98.9 \%$ comprised of registered enterprise classified as micro-small enterprise (i.e., farmers, fishermen, workers, professionals, vendors, single proprietor). ${ }^{10}$ About half of the 88 million people live in the rural areas, where almost 80 percent of the country's poor live. About 40 million Filipinos live on less than $\$ 2$ a day. Overall, more than a third of the people in the Philippines live in outrageous poverty (over 30 million). Poverty is a significant problem for the Philippines, and in combination with high income inequality, and economic stagnation, it poses a serious threat to stability in the Philippines.

Agriculture is the primary and often the only source of income for poor rural people, who depend on subsistence farming and fishing for their livelihood. Illiteracy, unemployment and the incidence of poverty is highest among the upland communities, where ironically most of the rich natural resources abound. The country is rich in natural resources - i.e., agriculture, fisheries, forestry and minerals and should be a good base for resource based processing industries. But these sectors have failed to integrate into competitive agro processing industries, due to the high cost of materials and backward technologies compelled by the atomistic structure of the sector and dominance of traders. The country's production sectors have continued to stagnate, unable to modernize or integrate its sectors, and have low productivity compared to their international counterparts. Sadly the resource advantage is now being eroded

${ }^{10}$ The economy of the Philippines is the 4th largest economy in South East Asia and the 36th largest economy in the world by purchasing power parity according to the International Monetary Fund in 2009. A newly industrialized emerging market economy, it posted a real GDP growth rate of $5.3 \%$ in 2006 and $7.1 \%$ in 2007. Growth slowed to $3.8 \%$ in 2008 as a result of the global financial crisis. In 2009 , the real growth rate was $0.9 \%$. For the first quarter of 2010 the economy grew by $7.3 \%$ which was higher than the $3.6 \%$ forecast. At the end of the second quarter of 2010, GDP growth again exceeded expectations by coming in at $7.9 \%$. 
by the sector's uncompetitive structure, and the economy has shifted to the service sector and export of its human resources to continue to survive. Ironically the free market system had created the production sector structures and institutional infrastructure that have become the barriers to alternative supply structures that more competitive and provide for more inclusive growth or value added sharing.

Economic adhered faithfully to the neoclassical economics propagated by its former colonizer through education, their continuing political and economic governance via prescriptions from the IMF, the World Bank and the WTO. The Filipino adherence to market economics is grounded in deeply embedded political-cultural values and beliefs in civil liberties and human rights, which has been associated with economic concepts of free enterprise, free consumer choice and reliance on market competitive process economics, which provides an "economic rationale-" for the socio-political values. This is a formidable combination that has subtly turned market economics into a "secular state religion", which has made these beliefs a matter of faith in institutions, beyond the questioning of reason or even the evidence of -reality.

The populace not being able to follow the esoteric reasoning of market economics and its institutional implications, rely on their faith and belief that their founding values of freedom, equality, justice, free enterprise, etc., - are protected and nurtured by the democratic and liberal capitalist institutions that have been established and govern. Although the historical performance of these capitalist free enterprise institutions have shown a-disconnect with these founding values, the people's faith in these values preserved these institutions.

As one of the early subscribers to the policies of market economics and globalization, the Philippines have joined the WTO, despite the continued failure of market economics to improve the productivity and competitiveness of the country's atomistic production system. Resolution of the problem of enterprise scale and sector integration has become even more important to compete in the global markets where bigness and integration is the key to survival. In the meantime, Philippine economic growth continues to rely on the productivity of the top One Percent of the enterprises in its production system, while 98.9 percent micro-small enterprises continue to be an overwhelming economic load and the core of mass poverty.

\section{Institutional Structures and Economic Impasse}

Free market capitalism has been established in the Philippines as the basic policy and legal framework for "good economic governance". Despite the continuing economic fall Philippine economic managers, business leaders and academics continue to follow and preach market economics and globalization as providing the "economic reasoning" that defines the path to development, and that policies should follow the conventional set of globalization (neoclassical) policy prescriptions of - free trade, free market competition, minimal government, follow the market signals, privatization etc. The defense varies: it is said that the market system has not been working because of imperfections in the Philippine market system, that there is corruption, monopolies, or government interventions in price support, that do not provide for a perfect competitive environment. It is said that the solution therefore is "good governance", that is to take away the "market imperfections" (the so-called transactional 
costs), and create a truly free or competitive environment, then the investors, entrepreneurs will come to establish the enterprise necessary to supply the demand.

What cannot be denied, however, is that the economic logic of maximization of self-interest thru efficiency" has been at work in the oligarchic feudal society, which has impacted and merged with the non-economic institutions and activities of society. In the abstract world of mathematics, market economic theory- "can freeze" the influence of institutional conditions (with an assumption of "all things being equal") in order to derive the "efficient market solution". But in the real world, the market system cannot prevent or confine its impact on the total spectrum of social activity and its varied institutional systems. What is held in theory and institutional design is, in fact, soon taken over by political and economic power as the market institutions are installed and become operative. In short institutional systems are not neutral in application, nor faithful to their theoretical intent. They evolve, and interact with other social building systems and humans who use them for their own purpose.

Neo-classical economists see society's economic behavior as being determined by one "holistic system", i.e., the economic resource allocation system, that maximizes self interest subject to constraints or initial conditions i.e., technical, resource and institutional in nature. The reality is, the social space is occupied by a hierarchy of systems within a system, or what Arthur Koestler calls "holons" (A. Koestler, first published in 1940: Darkness at Noon). ${ }^{11}$ A holon is a whole, and at the same time a component or a part of another whole. So, what we have is a system within a system within a system and so on, acting like the circles of ripples (each representing a social system) radiating when a pebble is dropped (i.e., when a systemic choice is made). There is a succession of pebbles dropped over time (representing the impact of social choice), causing the ripples to interact, changing their shapes thus "evolving the social systems". A holistic view of economics considers its system, as the sole system (circle) occupying the whole of social space, and treats the other systems as external parameters that are neutral and unchanging. On the other hand, a holonic view sees the reality of many systems (social, technical, natural, etc.) and economics being just one of them, simultaneously working and interacting with each other in the social space to build a nation.

An integral or holonic view of reality sees the impact of choice within the economic system, affecting the other natural and social systems involved in building a nation (i.e., natural resources, ecology, socio-cultural, moral-philosophical, production, financial, political, legal, administrative, psycho-cultural). The institutional impact of the economic logic on the institutions of the social systems of society, has been translated into structures, organizations, policies, rules, social concepts, beliefs, values and mind-sets, which have become barriers to collective development and creation of new institutional forces that feedback and redirect the market system from its purpose.

${ }^{11}$ Arthur Koestler (5 September 1905, Budapest - 3 March 1983, London) was an author of essays, novels and autobiographies. His early career was in journalism. In 1931 Koestler joined the Communist Party of Germany but, disillusioned by Stalinist atrocities, he resigned from it in 1938 and in 1940 published a devastating anti-totalitarian novel, Darkness at Noon, which propelled him to international fame. 
The following defines the institutional impact and implications of market economics in the Philippines on other building systems in the social space, specifically on:

a) the structure of the aggregate production system;

b) the participation and institutional power of enterprise(s) in a product sector's value chain;

c) the competitiveness (or comparative advantage) of a sector production system vis-a-vis the global economy;

d) the financial system's use of power derived from capital scarcity;

e) politics or the role of the government and the legal system in economic governance;

f) the psycho-cultural system or the collective consciousness of how we see economics.

\section{Production System Structure for a Dead-End Economy}

The first critical institutional impact of the economic logic of efficiency is on the structure or overall productive capacity of the economy, as a result of the prevalence of micro-small producers in a feudal economy. Macro-economic statistics measure aggregate performance, but it is equally important to see the participation and benefit of the constituent components of the production (particularly in a feudal oligarchic society) as a result of applying an economics of efficiency through a mechanism of free market competition.

As can be expected, installing an economic mechanism like this in a feudal, oligarchic society as the Philippines, has resulted in further concentration of wealth to the few landed and politically powerful families, who are the only ones to whom the efficiency ruled financial and business systems provide capital and technology resources. ${ }^{12}$ The smallness and individualized operations of the micro-small producer technically predetermines its economic disadvantages i.e., - a fragmented sector structure, high business risk profile, institutional disqualification for access to capital, no market leverage, inability to use of improved technologies.

This highly skewed so-called " $10-90$ " production structure can not go far in terms of generating taxes, savings, or income to support to support the basic needs of a growing population now 90 million. The problem of scale and individualized operations (atomistic structure) poses a technical problem (i.e., diseconomy of smallness), which can not be solved within the market system unless there is a pre-existing social infrastructure or culture of "trust" (such as guilds in Germany, keiretsu in Japan, kibbutz in Israel) which brings individuals to work together as a collective or networked enterprise. This generally requires a high degree of sociability or trust brought about by a country's history and culture, but the four hundred fifty years of colonial rule, feudal structure, individualism and market competition have nurtured

12 The Income of the top 10 percentile earns $40 \%$ of national income; $30 \%$ are below the poverty line, Micro-Small Enterprise comprise $98 \%$ of registered enterprise, but earns only $33 \%$ of gross value added. 
the divisiveness and atomization of the Philippine production sector, rather than arrangements of trust.

\section{Trader Takeover of Production Sector}

The efficiency principle impacts on the role of the individual economic enterprises at work in the product sector structure, in other words, the value chain of players that delivers the product from raw material to the market. The smallness and atomized structure of agri-based products (including forest, fisheries, and crafts) has compelled the micro-small producers to rely on layers of traders to access markets, production inputs and production capital. These traders also double up as financiers (informal lenders) who then gain control of their material production and fix prices and control flow of materials. This makes the material costs of the sector high priced, inefficient and uncompetitive in the global market even in products where the Philippines is the majority supplier, such as coconut.

The traders network supported by bigger capitalists, have become a monopsony or cartel ${ }^{13}$ and taken over control of the sector, maintaining a low survival farm-gate price for the fragmented micro-producers, and making their inventory profits as world market prices move. Because of the atomistic structure and smallness of the farm enterprises, and capital starvation of these high risk micro-producers, the commodity traders have taken effective control of the sector, to cater to their trading profit interests, to the detriment of the growth and competitiveness of the producers. Government adherence to free market policies have served to sanction and protect the trader capitalist's predator activities as a free enterprise response to a credit vacuum, likewise created by a banking sector response to the logic of efficient capital allocation. Democratic government 's avowed political promise of equality and responsibility for nurturing the disadvantaged give way to the more powerful demand of market winners for free enterprise and protection of private property.

The coconut sector is a classic case of trader takeover of "a would-be competitive industry" for the Philippines, which has prevented further industrialization or domestic value added growth into coco-chemical products and consumer products. Note that the Philippines is the largest producer of coconut and exports 80 percent of its coconut oil to Europe and United States, while Indonesia (second largest in coconut production) keeps roughly 80 percent of its coconut oil for domestic processing, and exports 20 percent. This shows the failure of the Philippine coconut sector to integrate because control of the raw material (copra and coconut oil) has been taken over by the trader-capitalists who find it easier to export to the global market. Without a feedstock supply base that can provide competitively priced material, with reliable supply volumes, agri-based processors often suffer under-utilization of capacity, and are unable to produce a competitive processed product, despite the natural abundance of the raw materials.

${ }^{13}$ In economics, a monopsony (from Ancient Greek $\mu$ óvos (monos) "single" + ỏ $\psi \omega v i ́ \alpha$ (opsōnia) "purchase") is a market form in which only one buyer faces many sellers. It is an example of imperfect competition, similar to a monopoly, in which only one seller faces many buyers. As the only purchaser of a good or service, the "monopsonist" may dictate terms to its suppliers in the same manner that a monopolist controls the market for its buyers. The term was first introduced by Joan Robinson in her influential book, The Economics of Imperfect Competition. 
In the meantime, the Filipino coconut farmer continues to be the poorest farmer in the agri-sector, despite the escalation of world market prices of coconut oil. ${ }^{14}$

The Philippine coconut case is a typical case of how market competition in a feudal or atomistic structured resource based production sector, is taken over by the short term profit interests of trader-capitalists, who find it more profitable and less risky to trade than develop the local industry, notwithstanding its comparative advantage in resources. The same pattern of trader interests has happened in Philippine fisheries, forestry, mining, which has seen the exportation of agricultural and mineral resources to processing industries (for higher value added) in the developed countries, which has been the history of world colonization by dominant political nations.

Philippine forests of 7 million hectares were depleted down to 1 million hectares mostly through log exports until it was banned, but local wood processing has not grown because of a trader dominated material supply which has made it high priced and unreliable. Mining continues to be purely extractive with no local processing despite the rich mineral deposits, which could have provided the material resource base for a mineral resource based industrialization. This pattern is repeated in agricultural, forest, marine, or mineral resource based industries, which disproves the globalization myth that participation in the global market as an "export winner", implies a sector is on its efficiency path, nor does export trade mean that a sector's constituency gets integrated to the mainstream economy, or solves poverty. This has been the history of world colonization by dominant capital rich countries, which has now backlashed in terms of a grave global deficiency and imbalance in aggregate demand between developed and third world economies which has sustained the 2008 global recession despite billions of stimuli packages.

Market economic theory ignores the power of market winners to become a principal institutional force that can divert a country's productivity goals and undermine the market system's goal of pursuing efficiency thru competition. In the Western economies large corporations are accused of this disregard of national interest; in third world countries, it is the trader-capitalist cartel that uses the market for their own interests. Yet, this is justified socio-politically and protected by the legal system in the name of freedom, human rights and economic efficiency, and in compliance with international globalization agreements.

\section{Market Distortion of Real Competitive Advantage}

The theory of market economics declares that the efficient development path of a nation is defined by its projected sector market winners and founded on its unique competitive or comparative advantage. Orthodox economic thinking defines this efficient path to be where

${ }^{14}$ See also research paper of Isabelita M. Pabuayon, Rowena D. Cabahug, Stella Villa A. Castillo and Marlo D. Mendoza, of the Department of Agricultural Economics, College of Economics and Management University of the Philippines Los Banos (UPLB) College, Laguna 4031 Philippines, College of Forestry and Natural Resources, UPLB, "Key Actors, Prices and Value Shares in the Philippine coconut Market Chains: Implications for Poverty Reduction", published in J. ISSAAS Vol. 15 No. 1: 52-62 (2009). 
the country has an abundance of resources, or so-called factor endowments. As a country richly endowed in agricultural or natural resources, the Philippine's natural comparative advantage and efficient development path should be in agro-processing industries, and should be at least self sufficient in food grains.

The question is asked: has the market mechanism of competition enabled the Philippines to accelerate its development along its path of competitive advantage? The answer is negative, and, in fact, the market competition mechanism has led to the erosion and eventual lost of the country's competitive advantage in the key sectors where it had an abundance of natural resources.

Instead these product sectors have lagged way behind in productivity compared to their international counterparts. This poor productivity is rooted in the feudal setting and atomistic structure of the producers who own or use these natural resources, i.e., farmers, upland tribal communities, fishermen, etc. Within this production sector environment, the dominant market winners in the sector, the trader-capitalists have taken over control of the supply of the micro-small producer, the sector's distribution flows, dictating prices and controlling volume of material supply to processors. Thus in "pursuing efficiency" the sector's market winners (the traders) have made the agricultural material base high cost, uncompetitive, and an unreliable base for a material processing industry. This has happened in agriculture, forestry, fisheries, minerals - all of which have rich economic potentials for processing into higher value added.

This has caused economic managers to abandon agriculture and natural resources as a base for the country's comparative advantage as discerned from the policy priority given to market winner sectors and liberalized importation program. Following market signals, economic managers have declared that the country is better off importing rice than to bid for self-sufficiency in rice, which has made the Philippines the largest importer of rice, despite its rich agricultural resources. Forest based industries have become uncompetitive as a result of intervening layers of trader-capitalists, responding to profit signals of the market. While the mining sector is considered be an export market winner for raw material exports, domestic processing of extracted materials is not in the plan. In effect, the institutional impact of the market system, creates a new institutional force and incentive (i.e., the trader-capitalists and raw material exports a low capital, low risk, quick return enterprise) have diverted the nation from its path of efficient development defined by its natural comparative advantage. Economic managers have misread the market results by interpreting these as the road map to efficiency, failing to see the impact of their compartmentalized economic view of social reality, and ignoring the institutional power of market winners to distort overall system efficiency and collective benefit.

\section{Institutional Creation and Scarcity of Capital}

The impact of the economic system on the financial system is probably the most common place, yet, profound and powerful. The basic economic relationships and principles emanate from the resource allocation problem translating production inputs to output in physical terms to maximize "self interest". The financial system gives the economic 
problem formulation a measurement of value - by equating self-interest to financial profit. Mathematically, this means equating the multi-dimensional concept of utility or self-interest to a single scalar value, in other words, profit. Through the "financial institutional system" financial assets (money, securities and derivatives) then become a medium of exchange and a store of values, which becomes a measurement of capital. Capital, which is the value of production flows from an asset (or factor of production) is also premised on an institutional (legal) system of property.

In effect, the "creation" as well as "scarcity of capital" can be invented or controlled by the underlying institutional system of finance, law and government. This places the creation and control of capital resources in the hands of financial institutions in particular, the Central Bank. The financial system is where free market economics has been most active and doctrinaire to the detriment of the less developed nations. Ironically it is in this free capital market where the market system has admittedly failed, with the global capital market fall of 2008. The debacle has been traced to the institutional manipulation of the market theory assumption of the direct correspondence between physical production and financial values, through unsound financial derivatives.

The impact of economic efficiency on the financial system in a feudal oligarchic country like the Philippines, is probably the most adverse market force that has worked against equality, integration and even economic efficiency itself. Capital scarcity has been used as the most effective instrument for maintaining and expanding political-economic control in all sectors. Formal credit sources following market rules set by Central Bank and the Department of Finance, have used the principle of economic efficiency to justify extremely conservative financing rules, which has led to a nationwide deprivation of credit to micro-small producers and a virtual abandonment of its financial function to the agricultural and rural economy, except for consumptive activities and deposit taking. ${ }^{15}$

On the other hand, rural trader capitalists have shown a more creative institutional attitude to capital, by virtually monetizing or "capitalizing" the land or production assets of micro-producers to production capital, in return for control of their produce. It is their "institutional confidence" that these production assets can be turned to cash that leads them to recognize the capital value of agricultural land, crops or fruit bearing trees, which the formal financial and economic institutions refuse to recognize.

In industry, the high cost of capital, the absence of long term funds, and the conservatism of banking institutions, under an IMF controlled Central Bank have prevented industries from investing for technology modernization. Philippine Programs initiated to bring in low cost long term funding from development assistance funds for targeted sector priorities, had been stopped by the Central Bank in compliance with the IMF - World Bank Guidelines to maintain uniform market price of capital, effectively converting government development banks to commercial banks, ignoring the legislated developmental role of government financial

\footnotetext{
${ }^{15}$ Agricultural credit comprise only $2,3 \%$ of the banking sector loan portfolio, and even this was largely for the big scale agricultural companies.
} 
institutions in third world economies. The same programs were adopted by more liberal financial institutions of East Asian neighbors who were more independent of Washington, and have been able to modernize and integrate their industries, as in Thailand for agriculture for processed food, Korea for its car industry, Singapore for its airline maintenance and repair, Indonesia for its processed coconut oil, Malaysia palm oil oleo chemicals.

Indeed, the financial power derived by the financial sector from market economics has become a major socio-political power in the development and governance of nations, an institutional implication effectively wielded by the hegemony of the lead market winner nations in coalition with the local oligarchy.

\section{Government Abdication to Market Rule}

The biggest institutional impact or implication of market economics is on the role of government in the economic life and development of a nation. For the market system, government is potentially the "biggest institutional enemy" because it has the legal authority and political power to change the institutional framework (or social space), where the market operates. The legal system through legislation and regulatory authorities can constrain or direct market behavior, and as such considered the principal rival force of market competition.

Economics present two extreme alternative governance systems - one driven by collective "free choice" through market competition or the other driven by the state or government planning. The choice of economic system is a Political decision or "institutional" in nature and not a matter of market force or economic logic. The extremes have become the ideological battleground between democracy-capitalism versus communism-central planning. In between the two extremes are variations of degree of government intervention where the Asian Model plays.

The Philippines lean to a doctrinaire or virtually a fundamentalist application of market economics in its economic governance. The Filipino faith in capitalism is finally rooted in their socio-cultural values for freedom and human rights, which has been used by market winners in the feudal society to fortify and legitimize their political economic-oligarchy. The free rein of market competition in a feudal country has led to further concentration of economic and political power among the few rich and powerful, who use "economic rationality" as their first line of defense against policy, legislative or institutional reforms that undermine their market power. Ironically, the marginalized sectors stand together with the oligarchy's political position, because of their socio-cultural value for freedom and human rights, which is associated with market rule principles. They fail to appreciate the legal and political connection between the market system and their socio-political institutions. Furthermore, they fail to see that their moral-social faith in the free market competition process has served to neutralize the most potent entity, i.e., the government that could economically empower the marginalized masses for global competition. And finally and most importantly, they fail to realize that "a level playing field" is implicitly discriminatory to the micro-small producer in a global market where bigness and integration is essential for techno-economic efficiency. This delusion is legitimized and sustained by institutional commendations and economic assistance 
given by IMF -World Bank to governments and their economic managers who follow their market policy prescriptions.

In summary, to respond to the task of assessing the effectiveness of market competition as the economic system and address the problem of mass marginalization, this article has taken an integral view of the hierarchy of varied building (social) systems at work in society.

The basic assumption of economics is that the market system and the building systems in the social space, including the market players are institutionally neutral (so, no monopoly or monopsony power), and that this compartmentalization remains constant through time despite the institutional feedback or impact on other social systems. The reality is that these other social systems are very much affected by the market system, and, hence, reshape themselves and the institutional conditions in the market. In a feudal economy, this has been seen to work against the system's basic purpose goal of collective economic efficiency for society.

This is not to say that economic efficiency is not important or useless, but the context of its application is largely dependent on institutional assumptions, which limit the scope and meaning of the market results. While efficiency is a principle that can be applied universally, the efficient solution is contextualized by the operative resource, technical and institutional assumptions of the market system. The validity and meaning of "efficient" must then be interpreted within these assumptions, including the reaction of other institutional systems to the market.

The tendency of social disciplines to reason within their own neat compartmentalized system and then presume its universality, has been the major source of social misery and oppressive fundamentalism. This has not been limited to economics. In this way social systems contrive and legitimize their own "partial" version of truth that should reign supreme within their own share of the social space, as though reality can be partitioned. It is this fundamentalism (arising from a compartmentalized holistic view of social or building systems) that has generated intellectual myths and conventions such as: the separation of church and state; economic rationality versus political or populist thinking; the distinction between legal evidence and factual reality, or that freedom can be compartmentalized into political or economic freedom that have caused systemic social disorder until history brings them to the final bar of reckoning - reality.

\section{Answer to the Final Question}

In conclusion, we go back to the central question - can the market system of capitalism, which developed market winning nations and marginalized masses through the mechanism of market competition, be the same social system to integrate the marginalized masses.

The answer can be "no" or "yes" depending on how one understands and applies market economics.

The answer is "NO" - if one sees and applies market economics with a doctrinaire or fundamentalist approach which prohibits any institutional change in the market system, because this would "distort the market forces in determining the efficient solution." The 
discussions in section 3 of this article show that this framework will wind up with varied institutional distortions and structural barriers that will perpetuate and intensify the concentration of wealth and marginalization of the masses of micro-small producers, as well as divert a nation's development path to that which serves the interests of the domestic oligarchy and market winners.

The answer can be "YES" - but that requires an integral system approach that recognizes the critical role of systemic institutional reforms to "empower in an integral manner" the micro-small producers or enterprises (MSEs) to compete in an efficient structure and scale. This integral approach recognizes the holonic structure of social systems that the market system is nested in as a hierarchy of natural, technical and social systems that interact and can control or rebuild each other.

Integralism ${ }^{16}$ recognizes that reliance on the market system to correct itself will not happen precisely because of the perpetuation or even fortification of institutional barriers by the market winners. The task of development or integration is to address the institutional "grid lock" which require a systemic choice. The case of the Philippines whose feudal oligarchic profile represents many third world problems, has been taken to identify the specific institutional structural problems or barriers that are generated by globalization economics. These points of impasse also serve to identify the institutional changes where systemic change can start.

\section{Systemic Choices to Rebuild a Nation}

From the beginning, mankind has had an intuitive grasp of the centrality of freedom in his being and role in the building of the earth. Human choice, the use of freedom, is the only planetary force that can build, sustain, destroy all the building systems of the earth (i.e., natural, technological, and the man-made social or institutional systems). Choice has defined the events of history, and they continue to govern and determine the life of a nation through the patterns of thinking and behavior that have become social institutional systems. Hence, the building and rebuilding of a nation also starts with Choice. ${ }^{17}$ The question is what choice brings systemic change. The article has identified the critical points of economic impasse brought about by institutional barriers or gridlock. These now identify the Systemic Choice to rebuild a Nation.

\subsection{Choice 1 - From Fundamentalism to Integralism - A Philosophy of Economic Freedom}

Market fundamentalism now rules the political economy of the Philippines. It is premised on the fundamental belief (or philosophy) that "maximizing self interest" through market competition compels efficiency, which will lead to the collective best use of resources and

\footnotetext{
${ }^{16}$ Integralism, or Integral nationalism, is an ideology according to which a nation is an organic unity. The term integralism was coined by the French journalist Charles Maurras. Integralism defends social differentiation and hierarchy with co-operation between social classes, transcending conflict between social and economic groups. Integralism claims that the best political institutions for given nations will differ depending on the history, culture and climate of the nation's habitat.

${ }^{17}$ However, in the context of this Article "Choice" should be understood and interpreted as a decision to take action.
} 
productivity. Market fundamentalism has been a powerful building force and system, because of its foundations on reason (economic), and its socio-political acceptance as the rational and free or liberal way of building a nation. As such in the Philippines, it has become an economic religion sanctioned by the oligarchy, the masses and the state through an ubiquitous institutional system with the force of law, political economic interests, and cultural faith.

Systemic change in a country ruled by market fundamentalism, compels an equally powerful idea which has the same organizing capacity - a new philosophy of economics described as "integralism". Integralism seeks the optimization of multiple goals within alternative institutional settings. While maintaining the need for efficiency, Integralism differs from market economics, in its the acceptance of multiple goals (other than economic or profit), to now include the valuation and ranking of multiple goals, the deliberate design or re-engineering of institutional arrangements and most of all the restoration of the primacy of human judgment - as the ultimate determinant of choice, and the creator of alternative market systems thru systemic institutional changes, rather than a mindless social process called the "market". In comparison market fundamentalism limits choice by removing or emasculating consideration of these multiple goals and treats them as exogenous to the market system. Alternatively non-economic benefits or costs are treated as externalities, which can be assigned a monetary cost, ignoring the incomparability of hierarchical ranking of priorities versus monetary values. As a result multiple goals or needs are reduced to purely economic terms, and tend to lose their moral or social value or role in the institutional building systems for development. This has become evident in the often inconclusive debates on the environment, population, and social justice.

Economists have professionally accepted and tolerated the deviation of economic theory from reality, but nevertheless the theoretical doctrines are alive and well reflected in the policies, regulations, and laws of the market institutional system, which are enforced "to the letter" and prohibit institutional changes - "to keep the doctrine" intact. This is because at root, fundamentalism is not about reason, nor values, it is about power. This has been the case with dominant belief systems, from superstition, religion, science, politics and economics even if the belief system is based on freedom. Now it is called "liberal fascism", where market reason or liberalism has become a "state religion". Ironically, while market fundamentalism has been instituted in the name of freedom of choice, it is its own dogmatism that surrenders that freedom to an "all knowing market process" and removes the role of deliberate informed choice to bring systemic change.

The Integralism philosophy incorporates the importance of economic efficiency but recognizes that this belief must be contextualized within the prevailing natural, technical, socio-political-economic conditions and institutional systems. Integralism makes it politically feasible to accept trade-offs among multiple goals (i.e., financial profit versus social equality, or environmental sustainability, etc.). In a world ruled institutionally by market fundamentalism, integralism represents a fundamental policy recognition that liberates institutional intervention that must nevertheless be collectively efficient. 
Integralism as a thinking and doing framework will liberate economic managers to deal with institutional issues (considered anathema by market economics), such as - the need for economic empowerment of MSEs trapped in an institutional production structure that perpetuates their smallness; the institutional creation of capital; restoring the role of government as an empowering steward of the people, and resolving other institutional blocks. This fundamentalism has been used by corporatism in the West, trader-capitalists oligarchies in the feudal third world, and now the globalization order seeks to perpetuate what Kenneth Galbraith calls "the economics of innocent fraud-i.e., the departure from reality of approved and conditioned belief in the economic world" without guilt or responsibility (Galbraith, J.K., 2004: The Economics of Innocent Fraud).

Integralism restores the role of Choice (i.e., socio-political) in economic governance, with the caution that the choice be in fact Integral, incorporating not only the concerns of techno-economic efficiency, but also the need to integrate the marginalized co-players in the production sector, sustaining the environment, bringing a nation to its place of dignity and fullness and essentially expanding the collective consciousness and freedom of all.

\subsection{Choice 2 - The First Water Lily - The Unit Building Block for Integral Change}

Everybody says we need systemic change, but ironically the hardest choice - the decision is to make systemic change happen. The fear is the System is Too big too change, Too big to fail, Too complicated to resolve within one's administration. Better to do something, no matter how marginal the impact. This has been the attitude taken by leaders who find systemic change too difficult to pursue and compromise to partial solutions, as may be noted in the aftermath of the 2008 financial collapse.

This fear or hesitancy to pursue systemic change, often emanates from a misunderstanding of the nature and structure of systemic change. Systemic change is confused with large scale change, which may just represent expansion but may not be systemic in nature. Systemic change means having a different system, a new way of seeing or doing things. Even if it is momentary, an exception to the rule, it represents a new integration, a new form of life, a hybrid, a new form of enterprise. Most important, thru an integrative approach, systemic change does not have to mean junking the whole prevailing system in favor a of totally new one.

Nature's biological system in fact shows that systemic change comes in the form of hybrids, or the entry of a new life form, an integral system that can propagate itself quite rapidly and even become dominant.

Such is the case of water lilies, which presents a strategy for systemic change through an integral unitary change, i.e., a new unit building block that can multiply rapidly. In the tropics, water lilies are notorious for rapidly populating a pond of water, once they are introduced to the pond. Other plants usually propagate through seeds, which take time to grow and increase. In the case of water lily, once a plant (an integral whole system) is introduced to a pool of water, it multiplies geometrically and can cover the whole pond surface. 
Like the water lily in the pond, systemic change can then be launched and expanded by developing and completing a new integral enterprise system, as the unit building block of a new system. Forms of enterprise have played a vital role in economic development of nations, such as the legal invention of corporations, franchised business, the organization of cooperatives, guilds, keiretsu etc., as an "institutional strategy" to address economic problems which can no longer be solved within the equilibrium of the market system. But the critical creative act or choice is designing and putting "the first water lily in the pond".

The Pooled Enterprise System - it is within this framework, that this article proposes the formation of "pooled enterprise system(s)" to respond to the problem of scale and trader-dominated sector structures, that characterize the rural agricultural sectors of feudal oligarchic economies such as the Philippines. This calls for the pooling of micro-producers' use rights, access or holdings of resources, into an asset pool large enough to provide a reliable and sustainable resource base. The pool aided by an integrator team secures a base market, processors, and investors, which will gravitate to the enterprise system, as the enterprise system is complete. The pooled enterprise system provides an organizational structure using an asset trust as legal - business vehicle, that maintains the individualism of micro production units, while integrating the sector players into a whole enterprise system which now has the scale and integrated structure needed for cost efficiency and market leverage. While there are existing cooperatives that undertake some collective action, the Resource Pool System transcend the scope and scale of economic functions undertaken by coops to include integration of the product supply chain in a region or province; pooling and sharing the supply chain's pooled value added, or converting the pooled resources into capital.

As this is written, applications for this integral enterprise system have been identified for key agricultural and resource processing sectors. But like the market system, the water lily must be introduced into the pond, in an exogenous manner, which the market system will not do. This requires a deliberate institutional choice to launch an integral pooled enterprise system in the production sectors.

\subsection{Choice 3 - Reclaiming Government Choice to Empower and Direct Economic}

\section{Governance}

Government (in our case the Philippine Government) abdication of economic governance to the market system, in a feudal oligarchic economy in the name of economic reason and liberalism, is effectively a surrender of the masses freedom to the local political-economic oligarchy. "Abdication or willful blindness" may be how to describe the consistent decision not to intervene in the workings of a system despite the reality of mass marginalization observed. The structural trap and system distortions (pointed out in section 3 of this Article) provides the factual basis and political-economic reason for the Government to reclaim its pro-active role in economic governance particularly to empower (in an integral manner) the disadvantaged masses to compete in a globalized market. The government's institutional move to open its local markets to global competition, creates an economic, political and even moral responsibility to now empower the disadvantaged masses to compensate for this new vulnerability and overwhelming competition. 
As has been done by every nation that has developed (under the Anglo-American Model or Asian Model), the Philippine leadership needs to define a vision for the nation's development along the path of its natural resource advantages, which - has been abandoned because of a misreading of market system signals. To define this vision will first require a different founding framework that is more integrative in its view of reality and attitude towards the openness and unity of social order. An integrative vision will require an intellectual framework that is founded on our total humanity and a whole earth, that recognizes social responsibility, and values that transcend a material and temporal world. Implementation will require the coherent translation of these framework and values to an institutional system and finally to an integrative human choice to empower and direct governance. There is a need to now recognize the naiveté of relying completely on the market system as the "mechanism of freedom" to define the course of a nation, and the need to deliberately define its efficient path of development of productivity, industrialization, and integration of the marginalized sectors.

The experience a feudal oligarchic economy shows that the market outcome reflect mainly the self interests of the political economic oligarchy. This truth and the resulting disillusionment of the masses with the political-economic systems of "freedom and economic reason" have provided the local leftists a following from the marginalized masses to pursue a revolution. But even as they criticize the inability of democracy and market economics to deliver the promises of freedom and equality, they substitute their own ideological fundamentalism as a poorly disguised bid for power.

\subsection{Choice 4 - Empower the 98}

In particular, the Government should now empower the 98 percent of the production system comprised of the micro-small producers, to provide the political will and institutional infrastructure to economically empower the micro-small enterprises to be "market efficient" and become a new productive engine for growth and stop being a heavy burden to the economy. This will require the political declaration of a national program to economically empower the 98 (the Micro-Small Enterprise Sectors) through an agenda of systemic institutional choices to support sectoral enterprise systems that can develop the competitiveness of the sector and achieve integration. This political decision is necessary to recognize that relying on the market system to bring systemic integration of the micro-small enterprises, can not happen because of its efficiency logic to weed out the uncompetitive.

\subsection{Choice 5 - Capital Creation and Scarcity Myth}

Globalization has propagated the economic myth to third world nations, that only foreign investments can save them to close the savings-capital gap which is the key to productivity development and income growth. While there is probably a lack of financial capital, third world countries often have substantial idle natural resource and production assets that have not been and can be translated to Capital.

In his book "The Mystery of Capital", Hernando de Soto had outlined the principles that can translate these assets into productive capital (Hernando de Soto, 2000: "The Mystery of Capital - Why Capitalism Triumphs in the West and Fails Everywhere Else", Basic Books). The key 
attributes of capital are three - that its value can be fixed, it is formal (i.e., documented), and it is negotiable. The Philippine network of trader-capitalists in the rural economy has recognized the capital value of farmer assets and has in fact capitalized the micro farmers' assets. They have attributed a capital value to the production assets they use (i.e. land, trees, crops, etc.), which they monetize (provide a cash advance) and use this to gain control of their produce and sell to their market links. This capital system though informal in nature has done more for the rural economy's capital requirements than the formal system of the banks and financial institutions.

The same logic for converting production or natural resources to assets can be undertaken to convert this to capital. The Resource Pool enterprise system as presented above presents an institutional scheme that effectively monetizes idle resources (or what de Soto calls "dead land capital") that can be used for productive use, or capitalized - if it becomes part of the resource pool system, which is linked to assured markets. The cash flows from the resource pool provide a basis for converting these flows to financial securities which can then be sold in the capital markets. Although unorthodox, this follows the institutional process of capital creation faithfully, and may be more transparent and verifiable than the layers of financial derivatives that have emerged from loan mortgages in the US that caused the Wall Street crash, because of their direct correspondence to documented performing productive assets.

The bottom line is Capital as a man made institutional instrument can be used to create resource scarcities or transform resources to capital - which can be harnessed to serve the productivity development of nations, but this requires an institutional decision to approach the market system, with an attitude of integralism for economic empowerment, rather than control thru scarcity, which is the essence of power, rather than freedom.

\subsection{Choice 6 - Integral Direction}

The basic direction may be summarized as follows: first, there is a need to get the country back on track on its real comparative advantage by addressing the institutional distortions and blocks generated by the market impact on the sector. The natural resource advantages are still basically there but the value added margins and profit have remained largely with the trader capitalists which has led to the development of trader business to the detriment of productivity growth that could be achieved thru sector integration. This is evident in agriculture when one compares the productivity of the same product (say pineapple) grown by individual farmers and those grown by an integrated plantation and processing.

Sector Integration into enterprise systems (such as the Resource Pool Enterprise System suggested) is the key to achieve higher productivity and integration of micro-small producers particularly in resource based industries which will require scale and integration of material production and processing in order to be efficient and competitive.

This sector integration will require government institutional support to redirect its present land reform from fragmentation of land (now happening because of land reform distribution of ownership) to pooling of land use whether owned by large or small holders. Government integration efforts in coconut has to be revisited and redirected along the resource asset pool 
scheme where farmer participation in the value added stream up to processing, can be made directly and not diverted by corporate processes and board member personal interests.

An agenda of systemic institutional reforms (or choices as presented by this Article) can be undertaken in a product sector where the country has an evident natural resource advantage, minus the market distortion of trader capitalists who have made the product high cost, low technology, low productivity. In this way, the feudal economy will be able to convert to Capital its vast untapped production, land and natural resources and resolve the debilitating hold of trader capitalists. Developing the resource processing industries (agricultural, forest, fisheries and mineral products) remains to be the efficient path of development. ${ }^{18}$ The path has been distorted by the prevailing market signals (created by a trader dominated production sector) saying that this land-rich agricultural country is better off importing rice, and exporting its people for overseas employment. This agenda of institutional systemic change can bring the Integral change needed in the production sectors to invert the prevailing so-called " $10-90$ " economy and thereby harness the 90 percent of the production system (composed of micro-small producers) and integrate them to the global order of economic efficiency and expanding freedoms.

\section{Conclusion - Finding the Filipino Identity - Building in the Way of Freedom}

"Our people must not forget, what we are, who we are, where we came from" - Emperor Matsuhito Meiji of Japan paraphrased from movie "the Last Samurai". 19

These were the words of the Japanese emperor to remember the vital and profound role of a people's identity and concept of who and what they are as human beings, in responding to the challenge of modernization (then being brought in by Admiral Perry and his ships). These words likewise remind Filipino's (and other nations) that the systemic choices they have to make to respond to the "invasion of globalization", must likewise be premised on an affirmation of their "collective self". To define a vision, presumes a purpose premise on a concept of an identity as a people. The emperor's words identify the principal dimensions of that "self".

The Philippines is essentially a nation of micro and small producers living in a group of islands that is very rich in agricultural, fisheries, forest, mineral, and touristic resources. Hence, the participation of this nation in the global economy should be grounded on this structure and resource endowment. While these define the demographic and economic makeup of the Filipino, it is his deep socio-political and moral belief in freedom and capitalism that has shaped his psycho-cultural make-up. It is his deep conviction that progress must come with and thru the exercise of civil liberties, which has led to a doctrinaire adherence to market economics enforced by a rigid institutional systems in finance, governance and laws. This

${ }^{18}$ The Philippine rural economy has an estimated at $\$ 60$ Billion of "dead land capital" that can become productive. Capital, as researched by this writer under supervision of Hernando de Soto in writing his book, The Mystery of Capital, see page 251.

${ }^{19}$ Emperor Meiji (3 November 1852 - 30 July 1912), or Meiji the Great, was the 122nd emperor of Japan according to the tranditional order of succession, reigning from 3 February 1867 until his death. 
market fundamentalism emanates from a long (450 years) history of colonization and revolution in pursuit of freedom, human rights, equality. This has ingrained a deep suspicion of politicians and government intervention, contrasted with a continuing faith in processes of free choice, i.e., market competition, free enterprise, elections, etc.

It is this "damaged culture" (as described by James Fallows in his book "Looking at the Sun") that has prevented the Filipino make the critical systemic political choices to correct the institutional setting for its people to compete in the global market of efficiency. As a result market fundamentalism has been institutionalized as "good governance" by governing political economic oligarchy endorsed by a bureaucracy and an academe indoctrinated with Anglo-American capitalism. The masses feel intuitively something is wrong as they see the contradictions of "economic reason and liberal social mechanisms" clash with the institutional demands of the realities in a feudal atomistic economy. But their faith in freedom and reason, lessons and values they have fought and died for, make them hesitate to make the socio-political choice needed to bring systemic choice.

The disillusionment with liberalism and market capitalism is not unique to the Philippine situation; it has become a civilization issue. The world has now seen how that the institutional systems of freedom can be used to wage war, steal elections, or legitimize a dictator. In 2008 a global economic deluge was unleashed by the financial system that has been the defender and praetorian guard of economic efficiency and the market system. The systems of freedom and economic reason are under attack globally, as the limits of their paradigms are exposed by social realities. The widening income gap and the continuing series of economic catastrophes attributed to a flawed market system, has triggered a global outcry for systemic change. But people are not ready to change the institutions of democracy and capitalism that have been the vehicle of freedom and economic reason, no matter the dire consequences they have endured for bearing these convictions that have become their identity.

While systemic change has become compelling and logical, it poses questions that the people and their leadership do not ask, much less answered. Where does one go if the ideas of freedom and reason seem to have failed? What is the alternative to democracy, and capitalism, and the critical values, social mechanisms, concepts and principles that have become essential to nation building and social order. The biggest nations have recoiled from the implications of systemic change, walking away with the fear that maybe the system has become too big to change.

A subtle deep seated intellectual - cultural impasse has set in because market fundamentalism has projected an "all or nothing" framework to systemic change, - i.e., that the market system is a monolithic system, and that any change in the system structures, or intervention in its relations, or building elements, will destroy the integrity and workings of the system. But this is like saying that one should not perform surgery or heal the human body (whose system balance is even more precise) even if there is a tumor that needs to be removed.

The critical difference that Integralism makes is that - it presents the contrary idea that the economic system is not one holistic inviolable system, but rather a holonic structured set of social building systems that can create many alternatives ways for transformation that to bring 
systemic change. The integrative framework for viewing reality and approach to systemic change, provides a critical understanding of the elements, structures, relations, processes and mechanisms, that build social order, which enables the nation builder to identify the subtle points of impasse and the critical choices that can bring systemic change, (as has been done in this article for the case of a feudal oligarchic country, i.e., the Philippines). The virtue of the integrative framework is that it avoids the danger of fascism or the fundamentalism that comes with success, because integralism is precisely premised on the plurality and diversity that freedom and reason provides, which is the essence of civilization's ascent. As such integralism is the best guarantee of freedom itself and the integrity of reason.

But it is, perhaps, in the Philippine case where integralism can prove itself as a framework for rebuilding a nation and as an alternative to the globalization myth that an intervention in the market system is an attack on the systems of freedom and reason itself. This intellectual lie has held back the Filipino people who continue to build their nation with democracy-capitalism as social systems designed by freedom and economic reason, to achieve progress, equality, justice and wholeness of a people. An integrative framework and social philosophy will enable the people to persist in their belief that a nation should and can still be built in the "ways of freedom", rather than by the power of market winners or political oligarchs Is this the case of people with a "damaged culture", an "idealism they can not afford" 20 or the test of democracy and capitalism as social systems that have betrayed their vow to freedom and the integrity of reason in the building of civilization?

We remember the words of the Filipino Hero Jose Rizal, ${ }^{21}$ who posed the question to those who would liberate nations - "what for freedom, if the slaves of today will be the tyrants of tomorrow". His words re-echo to a globalizing world that still has to learn how to build - in the "ways of freedom".

Perhaps Integralism, can set the course, as it liberates a people from the fundamentalism of a globalizing order and restores objective truth as the bar of reckoning, and leads a people to recognize their true self, their whole humanity, as they use their freedom.

\section{References}

Fallows, J. (1994). Looking at the Sun. The Rise of the New East Asian Economic and Political System. New York: Pantheon Books.

Fukuyama, F. (1998). The End of History and the Last Man. New York: Avon Books, Inc.

Galbraith, J. K. (2004). The Economics of Innocent Fraud. Houghton: Mifflin Company.

\footnotetext{
${ }^{20}$ James Fallows, "Looking at the Sun", words of the Prime Minister Lee Kuan Yew commenting on Filipinos, that their over-emphasis on rights makes them poor, page 367.

21 José Protasio Rizal Mercado y Alonso Realonda (June 19, 1861 - December 30, 1896, Bagumbayan), was a Filipino patriot and the most prominent advocate for reforms in the Philippines during the Spanish colonial era.
} 
Karnow, S. (1989). In Our Image: America's Empire in the Philippines. New York: Ballantine Books.

Koestker, A. (1940). Darkness at Noon. London: Vintage Books.

Pabuayon, I. M., Cabahug, R. D., Castillo, S. V. A., \& Mendoza, M. D., (2009). Key Actors, Prices and Value Shares in the Philippine coconut Market Chains: Implications for Poverty Reduction. J. ISSAAS, 15(1), 52-62.

De Soto, H. (2000). The Mystery of Capital - Why Capitalism Triumphs in the West and Fails Everywhere Else. New York: Basic Books.

\section{Copyright Disclaimer}

Copyright reserved by the author(s).

This article is an open-access article distributed under the terms and conditions of the Creative Commons Attribution license (http://creativecommons.org/licenses/by/3.0/). 